\title{
MLL/CBL Fusion Gene
}

National Cancer Institute

\section{Source}

National Cancer Institute. MLL/CBL Fusion Gene. NCI Thesaurus. Code C99343.

A fusion gene that results from a rearrangement of the $q$ arm of chromosome 11 which fuses the exon 6 of the MLL gene to exon 8 of the CBL gene. This rearrangement may be associated with acute myeloid leukemia and other leukemia types. 